\title{
INTER-RELIGIOUS INTERACTION IN CENTRAL KALIMANTAN: A Study of Islam, Christianity, and Hindu Kaharingan in Palangka Raya City And Eastern Kotawaringin
}

\author{
Desi Erawati ${ }^{1}$ \\ IAIN Palangka Raya \\ Email: desi.erawati@iain-palangkaraya.ac.id
}

\begin{abstract}
Central Kalimantan is one of the provinces in Indonesia where the population is heterogeneous in terms of religion, culture and ethnicity. In several regencies and cities, there are places of worship located side by side (eg mosques, churches, Balai Basarah, and Vihara). Religious relations in several locations indicate awareness of social relations based on kinship. This work is aimed at exploring the patterns of interaction between the life of religious communities in religious, social activities and cultural life. The study employs a naturalistic qualitative approach where the actual condition in the field is being observed or to be natural with the conditions as they are. The data is based on observation, documents and interviews with selected informants from various religious groups including those practicing Islam, Christianity, and Hindu Kaharingan. Two important findings of the work include, firstly, that the tolerance attitude among them is created because of the ideological strength of the local culture of 'Huma Betang' and the values of kinship. Secondly, the process of interaction occurrence is encouraged by the existed meaning of the 'front stage' (emphazising more on the interests of the group). It is an understanding of the differences among them without having to prioritize them in social life, culture and others as well as in the 'back stage' (personal self-concept) of being alert, prejudiced and more careful in daily communication.
\end{abstract}

Keywords: Inter-religious, interaction, interfaith, religion, Central Kalimantan

\section{INTRODUCTION}

Demographic conditions in Central Kalimantan with the upstream and

${ }^{1}$ The aithors would like to record a great gratitude to all parties contributing the availability of the paper. The research is funded by financial aids from Palangka Raya State Islamic Institute in 2017. Thanks are addressed to all informants from the city government, the Forum for Religious Harmony (FKUB) of both cities of Palangka Raya and district of East Kotawaringin. Thanks also go the citizens, especially in the AMACO complex and the village of Tumbang Kalang, who helped to produce a scientific work. The authors would also like to acknoledge the contribution of the Konferensi Antarabangsa Islam Borneo (KAIB) XI 2018 held in Pontianak as the paper was selected to be presented. The feedbacks from the conference are very valuable to the development of the final draft of the work. 
downstream areas of the river have made the composition of Central Kalimantan population diverse, both from ethnic heteroginity and religious sides. Central Kalimantan is classified as a heterogeneous region because there living various ethnicities such as Dayak, Javanese, Banjar, Madurese and Chinese (Cahyono, 2016, p. 40; Widen, 2017; Prasojo, 2017). The variety of existing communities can be seen from the number of religious groups in the cities of Palangka Raya; Muslims are as many as 221,972, Protestants are 87,245, Catholic Christians are 8,793, Hindus are 7,942, Buddhists are 3,154, and Confucius are 1,700 (Central Bureau of Statistics of Central Kalimantan Province). Meanwhile, the religious population in the Antang Kalang subdistrict is that Muslim population of 2,678, Protestant Christian of 4,093, Catholic Christians of 298, Hindus of 3,299, Buddhist of 3, and Confucianis of 20 (Sampit, 2017).

The research was carried out in the AMACO housing complex, with other two locations, precisely on Galaksi Street in the city of Palangka Raya. With the uniqueness of the location, it was found symbolic forms of tolerance as seen in places of worship such as mosques and churches side by side. This location provides harmonious tolerance between both parties. As an example, if there is a religious event by one of them, the other will help and provide with a place or space of parking for them. Then they would give permission to other religious followers to use mosque loudspeakers to announce the news from the community both bad and good ones of their religion. In addition, in social life in the community, people are very concerned on mutual cooperation of both at the event of death, marriage or celebration (Hadi, 2016). Similarly, the other location of the research field is in the village of Tumbang Kalang, Kotawaringin Timur Regency, Central Kalimantan, Indonesia. The indications of harmonious life are also seen in symbolic ways. For example, houses of worship among mosques, churches and Balai Basarah are located side by side (Harkrisnowo, 2010). The form of harmony is not only in adjoining places of worship but also in the relationships of social interactions existing in the community (such as attending and assisting in occasions of wedding, death, party of celebration). Other forms of harmony are also found in cultural aspects such as attending local traditional ceremonies as a form of appreciation and respect for fellow humans. Economically the members of the communities in the two research fields feel being supported each other in doing bussiness and other economical activities with a pattern of brotherhood rules and practices (Tamburian, 2018).

The interaction of inter-religious life in these two places is very harmonious. Life among religious people in the community is claerly indicated in daily 
communication including in the forms of helping each other and appreciating the difference beliefs. It is evidence of a tolerance practice in the case of the Muslim allowing their neighbours of different religious backround to use the sound system in the mosque for the announcement of news of death from a Christian family. Not only soundsystem, but the members of the communities are also allowed to sure other Mosque facilities such as toilet and parking lots. The people have a strong commitment of sharing the usage of faclities in the mosque, church and basarah as they also have an agreement to provide helps as needed for the maintanace of the facilities. The point is that they have agreed to respect their places of worships as necessary. When Jumat prayer takes place, the Christians will allow Muslims to use the front yard of the curch for parking considering the number of worshipers using cars and motor cycles is higher. The Muslims would also do the same for Cristians when they need helps on Sunday prayers.

The interesting and important phenomena mentioned earlier is related to the diversity of cultures, ethnicities and religious practices, especially in Central Kalimantan, that matter to the development of peace and harmony within a society. The portrait of harmony and social interaction from the case of Palangkaraya city and eastern Kota Waringin is pure and inspiring (Marshall, 2018). The communication activities between the people of diferent religious groups in their daily life show harmony and run in accordance with the wishes and expectations of each adherent 'lakum dii nukum waliadin' (Mietzner \& Muhtadi, 2018). From this statement, it is necessary to examine how the patterns of interaction between religious people among Islam, Christianity and Hindu Kaharingan (as local religions). Then what motives are behind the scene is also important to elaborate so other people learn from then practice of an interreligious relationship, especially in Central Kalimantan.

\section{METHOD}

The study is based on the results of a research project that employs a naturalistic qualitative approach. The reserach was conducted in two regencies in the province of Central Kalimantan. They include Palangka Raya Town and East Kotawaringin Regency. The total number of informants was 35 people, consisting of 22 Muslims, 6 Protestants, 1 Catholic, 6 Hindu Kaharingan, and having various professions from civil servants, mosque maintainer (Ta'mir), religious leaders, and the local public leaders. The informants' characteristics were selected according to the problem questioned related with their relationship with inter-religious harmony. The informants were deliberately chosen among religious leaders, the local public leaders and some informants 
were from the government and non government agancies (FKUB, chief of village, etc.).

The interview technique was carried out directly using a free interview model related with inter-religious interaction from various groups of Muslims, Protestants, Catholics, Buddhists and Hindu Kaharingan. To complete the documentation data in this study as supporting data, the researcher records data from the local religious affair offices, as well as from the Inter-Religious Harmony Forum (FKUB), the village office and the Central Statistic Center of Central Kalimantan province. Research observation was conducted by researcher from October - December 2016, and June - September 2017. Observation results were analyzed through daily records being evaluated every weekend. This evaluation is focused on patterns of interaction between religious people in their social lives.

\section{RESULTS}

Based on the results of observation related to inter-religious life in the fields, especially in Palangka Raya Town, Central Kalimantan, Indonesia, it can be seen that there is a significant sign of harmony indicated by the location if the buildings of places of worship which is adjacent to each other in several locations. For example, the location between mosques and churches is just on the next door of each other. This data shows the evidence of the very conducive relationship among interfaith social interactions. The religious life of the surrounding people can be seen in the pattern of social interaction as like the running of religious events such as the tradition of commemoration of Isra 'and Mi'raj, Maulid of the Prophet SAW, Nuzulul Qur'an during the month of Ramadan (Islamic traditions) and Sunday prayers in Christian tradition. In this case, the members of the community give supports to those having the programs of religious activities. The supports can be in the forms of physical helps such as parking space or suoud system as well as non-physical assistance such as respect and permission.

The other religious activities such as the Muslim holiday, the Eid-ul-Fitr holiday, and the culture of visiting each other on religious holidays are not only practiced by Muslims but also by people of other religious backgrounds. When the Christians celebrate Christmas and New Year, the culture of visiting each other is done by Christians and Muslims alike. In addition to religious holidays, good interactions are also done when there is a society member passing. Both Muslims and non-Muslims visit each other as to express the solidarity toward their fellow human beings/neighbors. The unique is that when the event is in the Christian place, the Muslim people will be provided 
with food which is made specifical for Muslim, halal food, so that Muslims are protected from forbidden food. ${ }^{2}$

The nuances of inter-religious harmony have been seen very warm as happening in the the two fields of research, especially in the village of Antang Kalang, Kotawaringin Timur district, Central Kalimantan, Indonesia. The local residents are united by blood relatives. The area has several places of worship adjacent to one another such as mosques, churches and basarah. The intension to have them located in the neoighboring place in one location is that they hope that tolerance will be created not only in the relationship between people, but also by the eixstance of the adjacent houses of worship. The relationship description of interaction among religious people in the village of Tumbang Kalang is very dynamic. It was in 2014 when the District level of Musabaqah Tilawatil Qur'an (MTQ) was held in that village. Tumbang Kalang village is chosen as the venue for the event. The organizing team was selected from Muslims, Christians, and Hindus of Kaharingan. They work together hand in hand to clean up the worship places and other facilities to support the program.

The local community strongly adheres to the customary values that they believe in. Customary values become a strong ideology as a foundation for creating harmony. It can be proven that blood ties become the source/ basis of the development of social order although they have different beliefs. Other patterns of interaction occur as the establishment of tolerance during the month of Ramadan. Young people and old people were very respectful of Muslims doing fasting. Therefore, the non-Muslims would respect the Muslims doing fasting by going to private area for drink, lunch and smoking. ${ }^{3}$

\section{DISCUSSION}

The interaction and relationship among interreligious groups of people is the result of the collection of information, ideas, concepts, desires, hopes, goals and messages of people when they are bound in a community setting as they need social order that requires personal understanding and awareness (Eder, 2010). An identity is certainly born from social interaction and communication. Identity is produced by negotiation through media, namely language (Parker et al, 2014). Therefore, a person's identity is determined by the appearance of one's own self, and the recognition. This explains that good communication among religious followers is evidenced by tolerance or good respect for

\footnotetext{
${ }^{2}$ This is based on interviews with several key informants from the two fields of research.

${ }^{3}$ The data is based on interviews in 2016 and 2017.
} 
religious people (Liliweri, 2009, pp. 42). Religious diversity is not a barrier to create harmony, because Dayak people in Central Kalimantan prioritize the power of brotherhood and kinship. This promotes an acknowledgment that arises within the people Central Kalimantan. The Dayak people believe that they have strong connection in terms of kindship and blood relationship as known with the term "oloh itah" within the people in Central Kalimantan.

The perception of people who have share similar identity and uniqueness is as a result of good social interaction among the people. For example, when someone says that 'I a Muslim, you are a Christian and you are Hindu Kaharingan' he unsderstand that the people's identity is totally different but they still understand and respect each other (Burhani, 2011). According to the Hindu Kaharingan philosophy, some terms are known in their teaching such as 'Penyang' that means to unite and have bond together, love and love. The 'Huma Betang' is meant to the purpose of the philosophy within their life. Although they different beliefs exist, they have to maintain a harmonious and peaceful life because the concept of "Betang Huma" is a long house that is inhabited by those having various backgrounds in which they can share, understand and tolerate and minimize the existing differences (Kdr, 2017). Describing social interactions that occur both in Palangka Raya Town and Tumbang Kalang Village, there are some findings that can be seen from the process (front stage)/ appearing on the surface of tolerance and being aware of the ideological differences. This can be said as an associative social process or a positive social interaction process in the form of tolerance, cooperation, and tolerance (Raihani, 2014).

In addition, the second stage is (back stage) or behind the surface or the human self-concept (internal). It can be said that the concept means how an individual can learn, adapt, understand a difference, both ethnic and religion. This is produced from the concept or understanding of a person without the influence of social interaction. It can be positive or negative thing. If it is negative, therefore, the interaction is less harmonious or there is a mistake in understanding the difference. It is evidenced in some people who still maintain a distance with different beliefs or different ethnicities. Like the Muslims with the symbol of Muslim clothing (headscarves) and their robes, they are not being Muslims only with their dress but are supposed topractice the teaching of Islam in their daily activities including their interaction with others no matter their tradition is.

There is a concern that disharmony is caused by the coming of outsiders or migrants by bringing exclusive concept/teachings. This asuption has been one supported by a case in Palangka Raya Town and Tumbang Kalang 
village. Responding to what they have heard about the rumor of the couses of disharmony theats, traditional leaders, communities and religious leaders sit together in order to discuss the prevention of unwanted conflicts. One example of the dissociative social processes is the emergence of antiphaty and prejudice based on non-flexible generalization. Antiphaty is usually being expressed or addressed to groups or individuals of a particular group of 'negative feelings' (Liliweri, 2009, pp. 199-200). This can be seen in the case of feeling afraid of entering the exclusive Islamic views, making the concept of Islam truly narrow and isolating themselves from other religious communities. The basis of social interaction between religious people is on how each process interprets the meaning of the communication received or captured (Amal, 2010, p. 168). For these issues is they gather to discuss the appropriate responses.

The communities believe that the proper interaction is supoosed to take place within the daily life. From several interviews with informants, it is found that their motives for living safely, peacefully and happily are based on local cultural values, such as blood relations, kinship or family. The concept of social interaction occurs because they are bound by the basis of kinship/ kinship. It is emmebaded in the concept of 'oloh itah'. The purpose of the proverb is that to guide people not to see the background of their faith in building daily interaction; whether Muslim or non-Muslim are the same in human life interaction. The Dayak in Central Kalimantan believe that if they enter the environment or region of Kalimantan and have the same mission of peace, togetherness, then they are considered by the Dayak people as brothers (Masduki, 2017). They also consider that the immigrants aretheir brother as well. From two different places, it can be concluded that the portrait of the creation of inter-religious harmony is evidence in both social and religious activities, both personally and collectively. The form of social interaction is in the form of mutual cooperation, friendship and participation in religious events which are certainly outside from the procession of ritually worship activities (Erawati, 2012).

\section{CONCLUSION}

The portrait of inte-relegious interactions among people in Palangka Raya Town and Tumbang Kalang Village occurs naturally based on the basis of cultural values and local norms inherited from earlier generation. The people have been able to continue the strong tradition although more chalanging world has influenced the sifting environment of modern life to post modern behavior in the gobal arena that also makes influences to many different aspects of life of the people in Central Kalimantan. The communities have 
been supported by several important evidfences as the work have founf them in the research. First, tolerance emerges due to the ideological strength of the local culture of 'Huma Betang Huma', blood relations and kinship. The local values have strongly influenced the way people think and behave in daily life, especially in terms of community interaction. Second, the process of interaction occurrence is caused by the existed meaning of 'front stage' (emphazising more on the interests of the group). It is an understanding the differences without having to prioritize in social life, culture and others as well as 'back stage' (personal self-concept) in which people need to be aware of their responsibelities of being careful of harmony and peaceful life in the community.

\section{BIBLIOGRAPHY}

Amal, B. S., \& Khusna, M. (2010). Anatomy and Development of Social Theory. Malang: Aditya Media Publishing.

Central Statistics Agency of Central Kalimantan Province. (n.d.) Retrieved September 2, 2018, from https://kalteng.bps.go.id/statictable/2017/11/01/592/jilangan-pemeluk-agama-menurut-kabupaten-kota-di-provinsi-kalimantan-tengah-2016.html

Burhani, A. N. (2011). Lakum dīnukum wa-liya dīnì: the Muhammadiyah's stance towards interfaith relations. Islam and Christian-Muslim Relations, 22 (3), 329-342. https://doi.org/10.1080/09596410.2011.586512.

Cahyono, A. S. (2016). The Effect of Social Media on Social Changes in Community in Indonesia. Publiciana Journal, 9 (1), 140-157.

Eder, J. F. (2010). Ethnic Differences, Islamic Consciousness, and Muslim Social Integration in the Philippines. Journal of Muslim Minority Affairs, 30 (3), 317-332. https://doi.org/10.1080/13602004.2010.515812

Erawati, D. (2012). Tolerance Model to Overcome Conflict (Development of a Model of Socialization of Mutual Values for Conflicting Religious Conflicts). Palangkaraya: Intrans publishing group.

Hadi, R. (2016). Religious Harmony Pattern in Banyumas. IBDA ', Islamic Culture Journal, 14 (1), 65-78.

Harkrisnowo, H. (2010). Multiculturalism in Indonesia: Human Rights in Practice. In W. El-Ansary \& D. K. Linnan (Eds.), Muslim and Christian Understanding: Theory and Application of "A Common Word" (pp. 189-200). New York: Palgrave Macmillan US. https://doi. org/10.1057/9780230114401 15 
Kdr, L. (2017). The Concept of Harmony According to the Hindu Kaharingan. Unpublished manuscript.

Liliweri, A. (2009). Prejudice \& Conflict of Communication Cross Cultural Multicultural Society. Yogyakarta: LKiS.

Marshall, P. (2018). The Ambiguities of Religious Freedom in Indonesia. The Review of Faith \& International Affairs. Vol 16, No 1. Retrieved September 2, 2018, from https://www.tandfonline.com/doi/full/10.1080/1 $\underline{5570274.2018 .1433588}$

Masduki, M. (2017). Tolerance in Local Culture-Based Plural Society (Case Study in Klepu Village, Sooko District, Ponorogo District). Socio-Culture, $14(1), 14-22$.

Mietzner, M., \& Muhtadi, B. (2018). Explaining the 2016 Mobilization in Indonesia Islamist: Religious Intolerance, Militant Groups and the Politics of Accommodation. Asian Studies Review, 42 (3), 479-497. https:// doi.org/10.1080/10357823.2018.1473335

Parker, L., Hoon, C.-Y. \& Raihani, (2014). Young People's Attitudes towards Inter-Ethnic and Inter-Religious Socializing, Courtship and Marriage in Indonesia. South East Asia Research. https://doi.org/10.5367/ sear.2014.0230

Prasojo, Z. H. (2017). Social Change and the Contributions of the Tionghoa, Dayak and Melayu (Tidayu) in West Kalimantan. In V. T. King, Z. Ibrahim, \& N. H. Hassan (Eds.), Borneo Studies in History, Society and Culture (pp. 427-442). Singapore: Springer Singapore. https://doi. org/10.1007/978-981-10-0672-2 20

Raihani. (2014). Creating a Culture of Religious Tolerance in Indonesian School. South East Asia Research. https://doi.org/10.5367/sear.2014.0234

Sampit, F. (2017). History of East Kotawaringin Regency. FKUB Office of the Ministry of Religion Kab. Sampit.

Tamburian, H. H. D. (2018). Cross Cultural Communication of Dayak Communities in Maintaining the Harmony of Religious Life. Journal of Communication, 10 (1), 77-86.

Widen, K. (2017). The Rise of Dayak Identities in Central Kalimantan. In V. T. King, Z. Ibrahim, \& N. H. Hassan (Eds.), Borneo Studies in History, Society and Culture (pp. 273-282). Singapore: Springer Singapore. https://doi.org/10.1007/978-981-10-0672-2_12 
